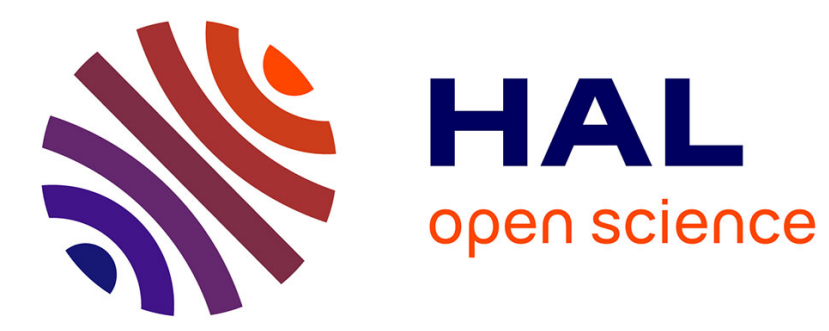

\title{
Somatostatin and somatostatin receptors in cushing's disease
}

Leo J. Hofland

\section{To cite this version:}

Leo J. Hofland. Somatostatin and somatostatin receptors in cushing's disease. Molecular and Cellular Endocrinology, 2008, 286 (1-2), pp.199. 10.1016/j.mce.2007.10.015 . hal-00531958

\section{HAL Id: hal-00531958 \\ https://hal.science/hal-00531958}

Submitted on 4 Nov 2010

HAL is a multi-disciplinary open access archive for the deposit and dissemination of scientific research documents, whether they are published or not. The documents may come from teaching and research institutions in France or abroad, or from public or private research centers.
L'archive ouverte pluridisciplinaire HAL, est destinée au dépôt et à la diffusion de documents scientifiques de niveau recherche, publiés ou non, émanant des établissements d'enseignement et de recherche français ou étrangers, des laboratoires publics ou privés. 


\section{Accepted Manuscript}

Title: Somatostatin and somatostatin receptors in cushing's disease

Author: Leo J. Hofland

PII:

S0303-7207(07)00391-7

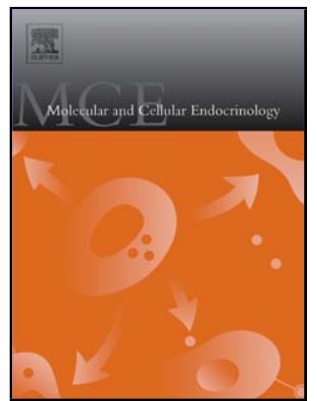

DOI: doi:10.1016/j.mce.2007.10.015

Reference: MCE 6730

To appear in: Molecular and Cellular Endocrinology

Received date:

4-7-2007

Revised date:

4-10-2007

Accepted date:

24-10-2007

Please cite this article as: Hofland, L.J., Somatostatin and somatostatin receptors in cushing's disease, Molecular and Cellular Endocrinology (2007), doi:10.1016/j.mce.2007.10.015

This is a PDF file of an unedited manuscript that has been accepted for publication. As a service to our customers we are providing this early version of the manuscript. The manuscript will undergo copyediting, typesetting, and review of the resulting proof before it is published in its final form. Please note that during the production process errors may be discovered which could affect the content, and all legal disclaimers that apply to the journal pertain. 
Figure 1

Hofland MCE

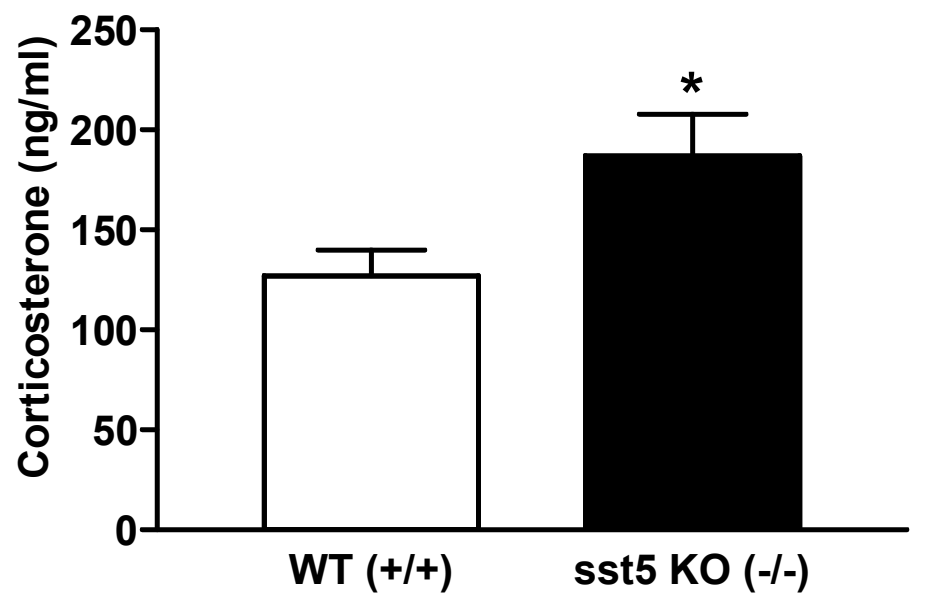

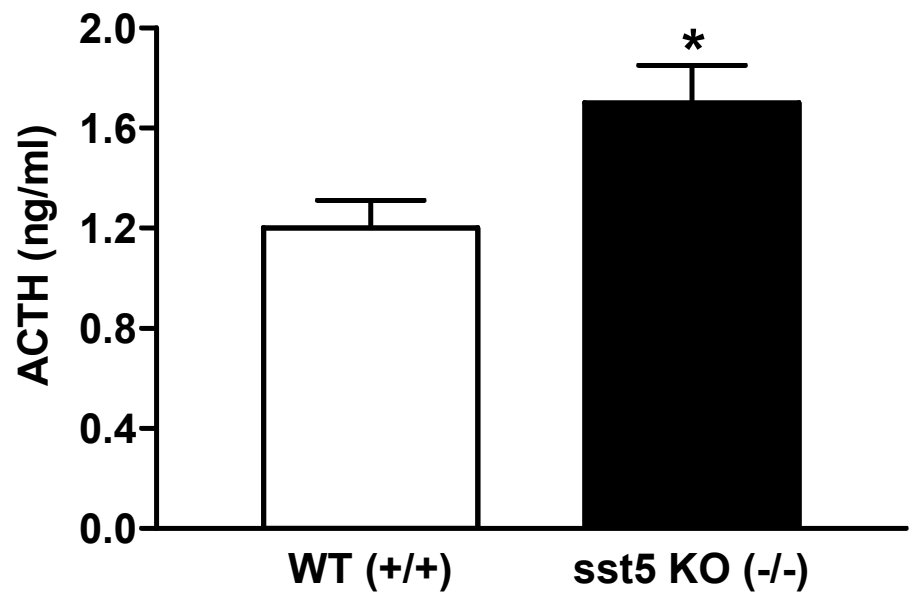


Figure 2

Hofland MCE
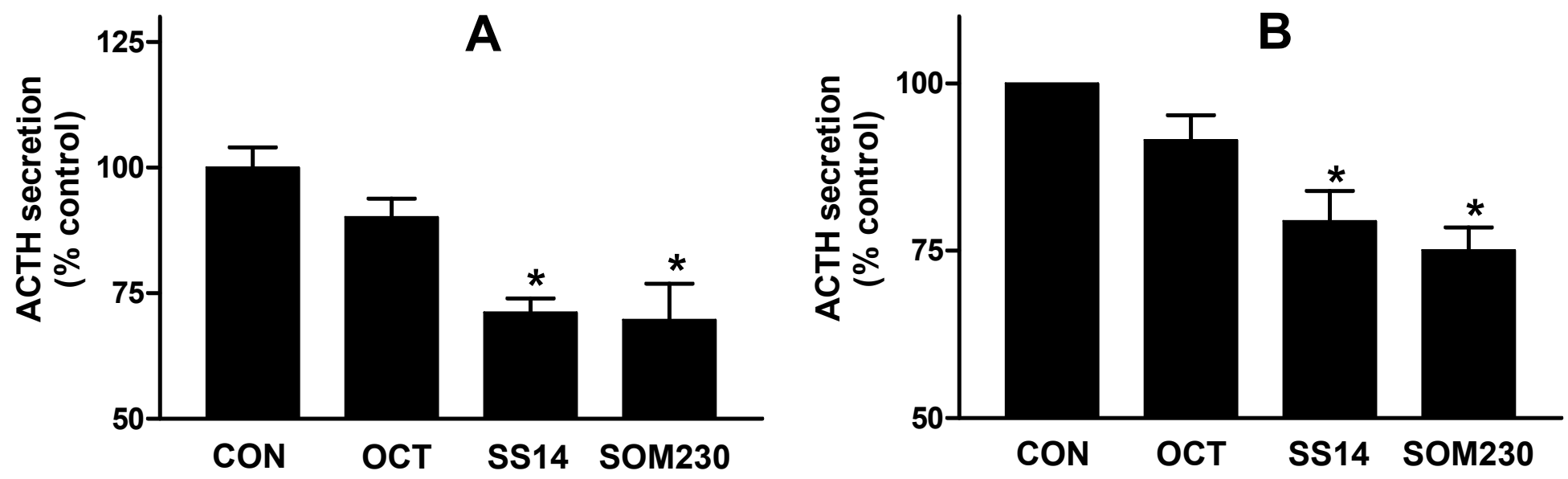
Figure 3

Hofland MCE

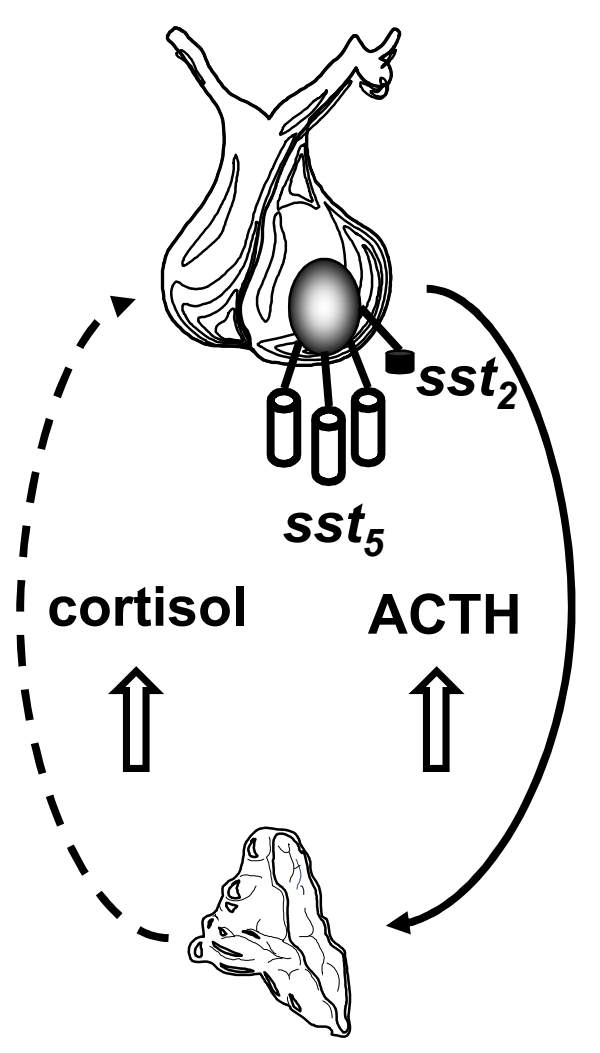

Adrenal cortex

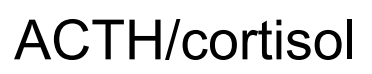

lowering

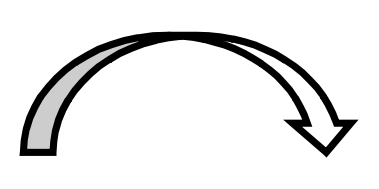

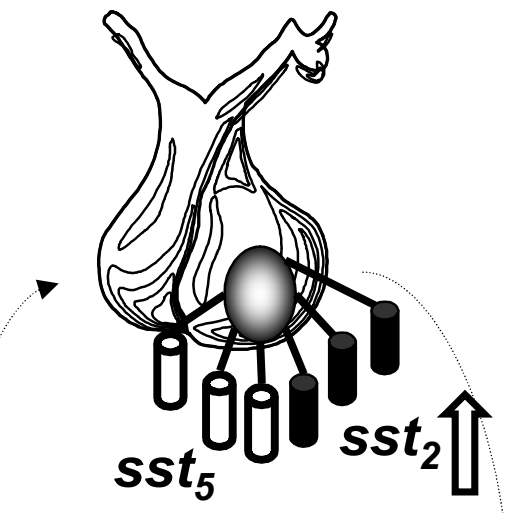

cortisol ACTH
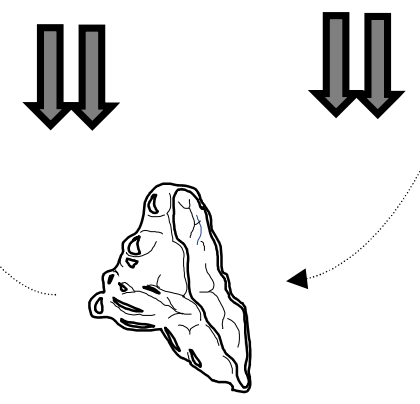

Adrenal cortex 


\title{
SOMATOSTATIN AND SOMATOSTATIN RECEPTORS IN CUSHING'S DISEASE
}

\author{
Leo J. Hofland
}

Department of Internal Medicine, Division Endocrinology, Erasmus MC, Dr. Molewaterplein 50, 3015 GE Rotterdam, The Netherlands

Correspondence: $\quad$ Leo J. Hofland
Department of Internal Medicine
Division Endocrinology
Room Ee530b
Erasmus MC
Dr. Molewaterplein 50
3015 GE Rotterdam
The Netherlands
Phone: +31-10-4634633
e-mail: 1. hofland@erasmusmc.nl




\begin{abstract}
Cushing's disease is caused by an ACTH secreting pituitary adenoma. Surgery is the treatment of choice and cure rates between 60 and $90 \%$ are reported. For patients in which surgery fails, effective medical treatment options are needed. Somatostatin (SS) receptors (sst) are expressed on normal and tumoral corticotroph cells. However, the role of somatostatin and in particular the current clinically available sst 2 -preferring SS analogs in the regulation of normal ACTH secretion, as well as in lowering ACTH and cortisol hypersecretion in patients with Cushing's disease, has been shown to be limited. Recent studies have provided renewed insights into the expression of sst subtypes, as well as into the functional role of SS-analogs in the regulation of $\mathrm{ACTH}$ secretion by corticotroph tumors. $\mathrm{Sst}_{2}$ and $\mathrm{sst}_{5}$ seem the predominantly expressed sst in corticotroph adenoma cells and targeting both these receptors with a new generation of multiligand SS analogs showed promising effects in terms of lowering ACTH release and urinary free cortisol (UFC) levels in patients with Cushing's disease. In this review an overview of the current insights into the role of SS and sst in the regulation of normal and pathological ACTH secretion is provided.
\end{abstract}




\section{Introduction}

Cushing's disease is associated with significant mortality and morbidity [1]. Removal of the ACTH secreting pituitary adenoma by transsphenoidal surgery results in cure rates between 60 and $90 \%$, depending on the localization of the tumor and the experience of the neurosurgeon [15]. If surgery fails, radiotherapy [6], alone or in combination with adrenolytic drugs, may be used [7-10]. Nevertheless, none of the current treatment modalities ensure a full and permanent cure as, depending on the criteria of initial cure, recurrence rates vary between 5 and $24 \%[6,11-15]$. Therefore, new medical treatment options are certainly required. One of the potential targets for such treatment include somatostatin (SS) receptors (sst) which are expressed on the majority of corticotroph adenomas $[16,17]$. SS was originally characterized as a hypothalamic peptide with a strong inhibitory activity on growth hormone (GH) secretion by the pituitary gland [18].

Thereafter, it was shown that the peptide has a widespread activity on various (neuro-)endocrine systems including the brain, pituitary gland, the pancreas and the gastrointestinal tract [19]. Two biologically active forms of SS consisting of 14 (SS-14) or 28 (SS-28) amino acids are present in the circulation and display a tissue specific expression. SS-14 and SS-28 act via high affinity Gprotein coupled membrane sst's. Five sst subtypes have been cloned and characterized. The genes encoding the five sst's are localized on different chromosomes [19]. The five sst subtypes, codenamed $\mathrm{sst}_{1}$-sst ${ }_{5}$, share a coupling to several second messenger systems known to be activated upon SS binding to its receptor. These systems include inhibition of adenylyl cyclase activity and activity of calcium channels, as well as stimulation of phosphotyrosine phosphatase (PTP) or MAP kinase activity. While the inhibitory effects on adenylate cyclase activity and on the influx of $\mathrm{Ca}^{2+}$ are linked to inhibition of secretion processes, the activation of PTP or MAP-kinase activity may play a role in the regulatory effects that SS may exert on cell proliferation [19]. More recently, another SS-like peptide, named cortistatin (CST), has been cloned and 
characterized $[20,21]$. Due to its high structural resemblance to SS, CST binds with high affinity to all five known sst subtypes [22]. CST has overlapping as well as differential activities compared to SS, particularly in the brain [23]. In the present review, the role of SS, CST, and related receptors in the regulation of normal and tumoral ACTH secretion by corticotroph (tumor) cells is discussed.

\section{SS and sst in the regulation of normal ACTH secretion}

In normal rat corticotrophs, co-localization of all five sst with ACTH expressing cells was shown [24]. Several studies demonstrated that both $\mathrm{sst}_{2}$ and $\mathrm{sst}_{5}$ receptors are expressed in rat corticotrophs $[25,26]$. The role of the individual sst subtypes in the regulation of normal ACTH secretion seems dependent, however, on the hormonal environment of the corticotroph cells. SS, at concentrations between 1-100 nM did not inhibit basal and corticotrophin releasing hormone (CRH)- induced ACTH secretion by cultured normal rat pituitary cells and pituitary halves $[27,28]$. On the other hand, SS inhibited CRH- and vasopressin induced ACTH release by cultured cells prepared from long-term adrenalectomized rats [29]. Moreover, in serum-deprivedor in rat pituitary cells pre-treated with the glucocorticoid blocking agent RU-38146, SS inhibited CRH-induced ACTH secretion already at low nanomolar concentrations, whereas in serum cultured cells SS was unable to influence ACTH secretion [30]. In humans, systemic SS infusion did not suppress basal- or angiotensin II-, ghrelin- or CRH-induced ACTH or cortisol concentrations [31-33]. Although differential activities of SS and CST on brain function have been reported, the endocrine activities of both peptides appear similar. Similar to SS, basal or ghrelin- and hexarelin- stimulated ACTH secretion was not suppressed by systemic CST infusion $[31,34,35]$. However, these studies only evaluated exogenous administration of SS or CST. Recent studies showed elevated pituitary proopiomelanocortin (POMC) mRNA levels in SS 
knockout mice compared with wild type controls [36]. Moreover, sst $_{5}$ knock out mice had significantly elevated ACTH and cortisol levels compared to wild type animals (Figure 1) [37]. In addition, it was recently shown in a group of ten healthy postmenopausal women that L-arginine infusion, as a putative suppressor of endogenous SS outflow, potentiates ghrelin- and CRHinduced ACTH secretion, suggesting that endogenous SS has a direct inhibitory role on ACTH secretion [38]. Finally, a recent study in rats showed that a $1 \mathrm{~h}$ pre-treatment with $10 \mu \mathrm{g} / \mathrm{kg}$ SOM230 (binds with high affinity to $\mathrm{sst}_{2}, \mathrm{sst}_{3}$ and $\mathrm{sst}_{5}$ ) inhibited $\mathrm{CRH}$-induced ACTH and corticosterone release in vivo by 51 and $27 \%$, respectively, whereas octreotide (binds mainly $\mathrm{sst}_{2}$ receptors) was significantly less potent at this dosage [39]. These latter data suggest a differential activity of sst subtypes in the control of ACTH release (see below). The stronger activity of SOM230 may be related to its higher binding affinity to $\mathrm{sst}_{3}$, and in particular $\mathrm{sst}_{5}$ receptors, compared with octreotide.

Summarizing, the currently available data suggest that SS may have regulatory effects on ACTH release under physiological conditions, but also that sst (or specific sst subtypes) expression is under negative regulatory control of glucocorticoids and that endogenous glucocorticoid levels may thus modulate SS action on the pituitary corticotroph cell.

\section{Expression of sst in corticotroph adenomas}

Initial studies using receptor autoradiography on cryostat sections of corticotroph adenomas failed to detect sst binding sites using the $\mathrm{sst}_{2}$-selective radioligand $\left[{ }^{125} \mathrm{I}_{-}-\mathrm{Tyr}^{3}\right]$-Octreotide [40]. In addition, in vivo sst scintigraphy using ${ }^{111}$ In-diethyltriamine pentaacetic acid (DTPA) octreotide showed no increased uptake in eight ACTH secreting pituitary adenomas [41,42], whereas positive uptake was found in two invasive ACTH macroadenomas and in two cases of Nelson's 
syndrome [41]. By using qualitative PCR, several studies showed the highest frequency of expression of $\mathrm{sst}_{5}$ and $\mathrm{sst}_{2}$, and to a lesser extent $\mathrm{sst}_{1}$ in corticotroph adenomas [43-46]. The high frequency of sst $_{2}$ mRNA expression in corticotroph adenomas, together with observation of the absence of octreotide ( sst $_{2}$ )-binding sites in vitro and in vivo, suggest that sst $_{2}$ expression is present on corticotroph adenoma cells, but at generally too low level to generate significant $\mathrm{sst}_{2}$ receptor protein expression. More recent studies using real-time PCR indeed showed that most corticotroph adenomas express $\mathrm{sst}_{2}, \mathrm{sst}_{5}$ and $\mathrm{sst}_{1}$, and that $\mathrm{sst}_{2}$ expression is in the majority of cases low compared to $\mathrm{sst}_{5}$, the latter being expressed at highest level $[47,48]$. Moreover, also at the protein level, sst $_{5}$ receptors were expressed at the highest level in corticotroph adenomas [48]. These data suggest that the $\mathrm{sst}_{5}$ receptor may be a novel potential target for medical therapies aiming to lower ACTH secretion by corticotroph adenomas.

\section{Role of somatostatin and its analogs on ACTH secretion by corticotroph adenomas}

The sst $_{2}$-selective SS-analog octreotide has no effect on basal and $\mathrm{CRH}$-induced ACTH release in patients with Cushing's disease [49-51]. On the other hand, octreotide and somatostatin suppressed ACTH serum levels in patients with adrenal insufficiency (Addison's disease) [52] and in patients with Nelson's syndrome [51,53]. Since Addison's disease and Nelson's syndrome are accompanied by hypocortisolism, it has been suggested that the missing effect of octreotide in patients with Cushing's disease could be due to a down-regulation of sst at the hypercortisolemic state [54]. This conclusion was further underlined by the in vivo observation that octreotide had no effect on circulating basal- or CRH-induced ACTH levels, whereas in the same study octreotide inhibited basal- and CRH-induced ACTH release by corticotroph adenomas in vitro in four of six and three of three cell cultures, respectively. Moreover, hydrocortisone pre-treatment in vitro abolished the inhibitory effect of octreotide on tumoral ACTH secretion [54]. We 
recently showed that the multiligand somatostatin analog SOM230 (pasireotide), as well as SS14, were significantly more potent than octreotide in suppressing basal ACTH release by human corticotroph adenomas in vitro (figure 2) [47]. The potency of SOM230 in inhibiting ACTH secretion by corticotroph adenomas was confirmed in another study, in which ACTH secretion was inhibited by SOM230 in five of six corticotroph adenoma cultures by $23-56 \%$ [48]. The high affinity of SOM230 for the $\mathrm{sst}_{5}$ receptor, and the high expression of $\mathrm{sst}_{5}$ receptors in corticotroph adenomas may form the basis for this enhanced potency of SOM230 in suppressing ACTH secretion $[47,48]$. Indeed, studies in AtT20 cells expressing both $\mathrm{sst}_{2}$ and $\mathrm{sst}_{5}$ receptors, showed that SOM230 was also much more potent in suppressing basal and CRH-induced ACTH release than octreotide[47,55]. $\mathrm{IC}_{50}$ values of inhibition suggested a sst ${ }_{5}$-like response of ACTHinhibition. Both sst $_{2}$ and $\mathrm{sst}_{5}$ are involved in the inhibition of ACTH release and cAMP production in AtT20 cells [56] and a functional superiority of $\mathrm{sst}_{5}$ over $\mathrm{sst}_{2}$ has been suggested by others as well $[57,58]$. On the other hand, $\mathrm{sst}_{2}$ receptors, albeit at low level, are co-expressed with sst $_{5}$ receptors in corticotroph adenomas as well. Since SOM230 also binds with high affinity to $\mathrm{sst}_{2}$ receptors a coordinated enhanced ACTH-suppressive activity via both $\mathrm{sst}_{2}$ and $\mathrm{sst}_{5}$ receptors cannot be excluded. Such an enhanced activity is not readily explained by in vitro data, however. In CHO cells co-expressing sst $_{2}$ and sst , $_{5}$ as well as in AtT20 cells, SS-14 treatment (targeting both $\mathrm{sst}_{2}$ and $\mathrm{sst}_{5}$ ) induced a loss of $60-70 \%$ of sst binding sites and a massive $\mathrm{sst}_{2}$ endocytosis. On the other hand, selective stimulation of $\mathrm{sst}_{2}$ receptors resulted in only a loss of $20-40 \%$ of sst binding sites and markedly reduced sst $_{2}$ internalization. This was accompanied by desensitization of the response to SS-14, and absence of desensitization by the sst 2 -specific analog. These findings suggest that $\mathrm{sst}_{5}$ modulates trafficking and cell surface regulation of sst $_{2}$ and cellular desensitization to the effects of SS [59]. It also suggest that tumors co-expressing sst ${ }_{2}$ and sst $_{5}$ have sustained responsiveness to sst $_{2}$-selective SS-analogs and that SS-analogs targeting 
both sst $_{2}$ and sst $_{5}$ would induce desensitization more rapidly. This seems not in agreement with the in vitro observations in corticotroph adenomas in which prolonged exposure to SOM230 and SS-14 induced a more potent suppression of basal- and CRH-induced ACTH release, compared with octreotide (see above). Therefore, likely other mechanisms are involved as well. In addition, a recent study in AtT20 cells showed that SS-28 exhibited a higher potency (femtomolar), compared with octreotide (picomolar potency) on cAMP accumulation and ACTH secretion, while it was shown that, using monoreceptor-selective peptide agonists, sst $_{5}$ regulates a dominant $\mathrm{sst}_{2}$ action, attenuating $\mathrm{sst}_{2}$ effects on intracellular calcium oscillation and internalization [60]. Besides the suppression of ACTH and cortisol secretion, a secondary beneficial activity of medical therapy would be the inhibition of tumor cell proliferation. In AtT20 cells, neither octreotide, nor SOM230 inhibited cell proliferation or induced apoptosis, however [47]. Moreover, in rats, both octreotide and SOM230 inhibited adrenalectomy-induced mitotic activity in the pituitary gland of male rats. However, both drugs did not inhibit proliferation of ACTHimmunoreactive cells, while hormonally null cells were inhibited [61]. Taken together, it seems that $\mathrm{sst}_{2}$ and $\mathrm{sst}_{5}$ receptors in corticotroph tumor cells do not mediate a growth inhibitory effect. On the other hand, a recent in vitro study in six primary corticotroph adenoma cell cultures showed that SOM230 inhibited cell number in five of six cultures, as measured by a colorimetric (MTS) assay [48]. Since pituitary adenoma cells have very low proliferative capacity, it remains to be established which is the exact mechanism of this inhibitory effect of SOM230 on MTS activity in primary corticotroph adenoma cultures.

Preliminary in vivo data in patients with Cushing's disease showed that SOM230 has ACTH lowering activity. In an open label, single arm, Phase II multicenter study in 27 patients with de novo or persistent/recurrent Cushing's disease, SOM230 treatment for 15 days (600 $\mu$ g s.c. bid) 
resulted in normalization of free urinary cortisol (UFC) levels in 4 patients (19\%), while in 9 patients (43\%) there was a 50\% or more higher decrease in UFC. Overall, UFC levels decreased in all but one patient. Significant improvement of body weight was reported in $24 \%$ of patients. Mild-to-moderate gastrointestinal events and hyperglycemia were the most frequent adverse events. One patient with pre-existing diabetes mellitus had to discontinue because of worsening of glycemic control $[62,63]$. A more long-term treatment study should demonstrate whether this multiligand SS-analog can indeed be a novel medical tool to control ACTH hypersecretion and related severe symptomatology in patients with Cushing's disease. Moreover, since patients with Cushing's disease are known to suffer from glucose intolerance, such studies need to address the potential adverse effects on glycemic control. Impaired GH secretion usually accompanies Cushing's syndrome, in a significant percentage of patients even after long-term remission of hypercortisolism obtained by surgery alone [64]. In this respect, the potent suppression of circulating GH and IGF-I levels by SOM230 [65] should be taken into account as well, in particular in patients who are already significantly catabolic.

\section{Role of glucocorticoids on the regulation of sst expression of corticotroph adenomas}

The absence of inhibition of ACTH secretion by SS and the SS-analog octreotide in patients with Cushing's disease and the inhibition of ACTH release by SS(-analogs) in patients with absent endogenous glucocorticoid feedback, strongly suggest that glucocorticoids have a negative regulatory effect on the expression of sst receptors, most likely sst ${ }_{2}$ (see above). Indeed, dexamethasone treatment induced a down-regulation of sst binding sites in $\mathrm{GH}_{4} \mathrm{C}_{1}$ and AtT20 cells by $20-40 \%$ [66]. In $\mathrm{GH}_{4} \mathrm{C}_{1}$ cells, high dose dexamethasone $(1 \mu \mathrm{M})$ treatment for $24-48 \mathrm{hr}$ resulted in a decrease in $\mathrm{sst}_{1}(-50 \%)$ and $\mathrm{sst}_{2}(-30 \%)$ mRNA level, whereas $\mathrm{sst}_{3}$ levels showed a biphasic time-dependent response, e.g. inhibition at early time points and a significant increase 
after more long-term exposure [67]. Moreover, in adrenalectomized rats, eight days following adrenalectomy a specific upregulation of pituitary sst ${ }_{2}$ expression was observed [68]. Finally, high dose dexamethasone treatment induced a downregulation of sst $_{1-4}$ and an upregulation of sst $_{5}$ [68]. Our in vitro studies showed that pretreatment of AtT20 cells with dexamethasone abolished the inhibitory effect of octreotide, but not that of SOM230, on ACTH release. This was accompanied with a decrease of $\mathrm{sst}_{2}$ mRNA expression, whereas $\mathrm{sst}_{5}$ expression was significantly more resistant to the inhibitory effect by dexamethasone [55].

Taken together, these data provide strong evidence for the fact that $\mathrm{sst}_{2}$ receptor expression is under negative regulatory control of endogenous glucocorticoids, and could thus form an explanation for the observed low levels of $\mathrm{sst}_{2}$ and high levels of $\mathrm{sst}_{5}$ expression in corticotroph adenomas of patients with Cushing's disease, as well as for the lack of efficacy of sst $_{2}$-specific SS-analogs and the enhanced potency of $\mathrm{sst}_{2} / \mathrm{sst}_{5}$ specific SS-analogs on tumoral ACTH secretion.

\section{Summarizing conclusions}

From the current knowledge it can be concluded that multiple sst are expressed in corticotroph cells. Exogenous administration of SS or CST does not lower ACTH levels. However, suppression of endogenous hypothalamic SS outflow by L-arginine increases CRH- and ghrelininduced ACTH secretion. A role for endogenous SS in the control of ACTH secretion seems further substantiated by the increased $\mathrm{ACTH}$ and cortisol levels in sst ${ }_{5}$ knockout mice, as well as by the increased pituitary POMC expression level in SS knock out mice. The expression of sst is $_{2}$ under negative control of glucocorticoids, whereas sst $_{5}$ seems more resistant to the suppressive effect of glucocorticoids. Corticotroph adenomas express predominantly sst ${ }_{1}$, sst $_{2}$ and sst $_{5}$. Sst ${ }_{5}$ are expressed at highest level. Targeting multiple sst by SS-14, SS-28 or the multiligand 
pasireotide (SOM230), results in a more potent suppression of ACTH release, compared to the effect of the sst ${ }_{2}$-selective SS-analog octreotide. These observations formed the basis for a first Phase II clinical study with pasireotide in Cushing's disease and promising preliminary data have been reported. On the basis of this current knowledge a hypothetical model of the interrelationship between cortisol levels and the expression of sst subtypes (e.g. sst $_{2}$ and sst ${ }_{5}$ ) on corticotroph adenomas of patients with Cushing's disease is proposed (Figure 3). 


\section{Figure legends}

Figure 1: Basal ACTH and corticosterone levels in fasted wild type (WT) and sst $_{5}$ knok out (KO) mice. Animals were 3- to 6-month-old males fasted for 12-16h. Values are expressed as mean \pm SEM. Numbers in parentheses indicate the number of animals tested. $* \mathrm{P}<0.05$ vs WT mice. Adapated from [37].

Figure 2: Effect of Octreotide (OCT, 10nM), SS14 (10 nM) and SOM230 (10nM) on ACTH secretion by cultured cells from a human corticotroph adenoma (A) and by AtT20 pituitary tumor cells (B). Incubation time was $72 \mathrm{hr}$. Values are the mean \pm SEM. ${ }^{*} \mathrm{p}<0.01$ vs control (CON). Adapted from [47].

Figure 3: Hypothetical model of the regulation of sst $_{2}$ and sst $_{5}$ receptors on human corticotroph adenomas by cortisol. A de novo human corticotroph adenoma has predominant expression of sst $_{5}$ and low expression of sst $_{2}$ (left panel). The elevated ACTH and cortisol levels down-regulate $\mathrm{sst}_{2}$ expression on the ACTH-secreting pituitary adenoma, which may form an explanation for the lack of efficacy of the sst 2 -preferring SS-analog octreotide on circulating ACTH and cortisol levels in patients with Cushing's disease. Lowering of ACTH and cortisol levels by for example $\mathrm{sst}_{2} / \mathrm{sst}_{5}$ specific SS-analogs via targeting $\mathrm{sst}_{5}$ may lower ACTH and cortisol levels.

Subsequently, the down-regulation of sst $_{2}$ receptors by cortisol may be abrogated (right panel). When $\mathrm{sst}_{2}$ receptor expression increases, a combined $\mathrm{sst}_{2} / \mathrm{sst}_{5}$ activation may result in enhanced ACTH and cortisol suppression. The model may also provide an explanantion for the ACTH- and cortisol lowering effect of octreotide in patients with adrenal insufficiency (Addison's disease) and in patients with Nelson's syndrome, which have a hypocortisolemic state. Adapated from [69]. 


\section{References}

[1] Swearingen, B., Biller, B.M., Barker, F.G., 2nd, Katznelson, L., Grinspoon, S., Klibanski, A. and Zervas, N.T. (1999) Long-term mortality after transsphenoidal surgery for Cushing disease. Ann Intern Med 130, 821-4.

[2] Mampalam, T.J., Tyrrell, J.B. and Wilson, C.B. (1988) Transsphenoidal microsurgery for Cushing disease. A report of 216 cases. Ann Intern Med 109, 487-93.

[3] Trainer, P.J., Lawrie, H.S., Verhelst, J., Howlett, T.A., Lowe, D.G., Grossman, A.B., Savage, M.O., Afshar, F. and Besser, G.M. (1993) Transsphenoidal resection in Cushing's disease: undetectable serum cortisol as the definition of successful treatment. Clin Endocrinol (Oxf) 38, 73-8.

[4] Knappe, U.J. and Ludecke, D.K. (1996) Persistent and recurrent hypercortisolism after transsphenoidal surgery for Cushing's disease. Acta Neurochir Suppl 65, 31-4.

[5] Boggan, J.E., Tyrrell, J.B. and Wilson, C.B. (1983) Transsphenoidal microsurgical management of Cushing's disease. Report of 100 cases. J Neurosurg 59, 195-200.

[6] Sonino, N., Zielezny, M., Fava, G.A., Fallo, F. and Boscaro, M. (1996) Risk factors and long-term outcome in pituitary-dependent Cushing's disease. J Clin Endocrinol Metab 81, 2647-52.

[7] Colao, A., Di Sarno, A., Marzullo, P., Di Somma, C., Cerbone, G., Landi, M.L., Faggiano, A., Merola, B. and Lombardi, G. (2000) New medical approaches in pituitary adenomas. Horm Res 53 Suppl 3, 76-87.

[8] Miller, J.W. and Crapo, L. (1993) The medical treatment of Cushing's syndrome. Endocr Rev 14, 443-58. 
[9] Morris, D. and Grossman, A. (2002) The medical management of Cushing's syndrome. Ann N Y Acad Sci 970, 119-33.

[10] Orrego, J.J. and Barkan, A.L. (2000) Pituitary disorders. Drug treatment options. Drugs $59,93-106$.

[11] Yap, L.B., Turner, H.E., Adams, C.B. and Wass, J.A. (2002) Undetectable postoperative cortisol does not always predict long-term remission in Cushing's disease: a single centre audit. Clin Endocrinol (Oxf) 56, 25-31.

[12] Estrada, J., Garcia-Uria, J., Lamas, C., Alfaro, J., Lucas, T., Diez, S., Salto, L. and Barcelo, B. (2001) The complete normalization of the adrenocortical function as the criterion of cure after transsphenoidal surgery for Cushing's disease. J Clin Endocrinol Metab 86, 5695-9.

[13] Chee, G.H., Mathias, D.B., James, R.A. and Kendall-Taylor, P. (2001) Transsphenoidal pituitary surgery in Cushing's disease: can we predict outcome? Clin Endocrinol (Oxf) 54, 617-26.

[14] Rees, D.A., Hanna, F.W., Davies, J.S., Mills, R.G., Vafidis, J. and Scanlon, M.F. (2002) Long-term follow-up results of transsphenoidal surgery for Cushing's disease in a single centre using strict criteria for remission. Clin Endocrinol (Oxf) 56, 541-51.

[15] Pereira, A.M., van Aken, M.O., van Dulken, H., Schutte, P.J., Biermasz, N.R., Smit, J.W., Roelfsema, F. and Romijn, J.A. (2003) Long-term predictive value of postsurgical cortisol concentrations for cure and risk of recurrence in Cushing's disease. J Clin Endocrinol Metab 88, 5858-64.

[16] Hofland, L.J. and Lamberts, S.W. (2004) Somatostatin receptors in pituitary function, diagnosis and therapy. Front Horm Res 32, 235-52. 
[17] van der Hoek, J., Lamberts, S.W. and Hofland, L.J. (2004) The role of somatostatin analogs in Cushing's disease. Pituitary 7, 257-64.

[18] Brazeau, P., Vale, W., Burgus, R., Ling, N., Butcher, M., Rivier, J. and Guillemin, R. (1973) Hypothalamic polypeptide that inhibits the secretion of immunoreactive pituitary growth hormone. Science 179, 77-9.

[19] Patel, Y.C. (1999) Somatostatin and its receptor family. Front Neuroendocrinol 20, 15798.

[20] de Lecea, L., Criado, J.R., Prospero-Garcia, O., Gautvik, K.M., Schweitzer, P., Danielson, P.E., Dunlop, C.L., Siggins, G.R., Henriksen, S.J. and Sutcliffe, J.G. (1996) A cortical neuropeptide with neuronal depressant and sleep-modulating properties. Nature 381, 2425.

[21] de Lecea, L., Ruiz-Lozano, P., Danielson, P.E., Peelle-Kirley, J., Foye, P.E., Frankel, W.N. and Sutcliffe, J.G. (1997) Cloning, mRNA expression, and chromosomal mapping of mouse and human preprocortistatin. Genomics 42, 499-506.

[22] Fukusumi, S., Kitada, C., Takekawa, S., Kizawa, H., Sakamoto, J., Miyamoto, M., Hinuma, S., Kitano, K. and Fujino, M. (1997) Identification and characterization of a novel human cortistatin-like peptide. Biochem Biophys Res Commun 232, 157-63.

[23] de Lecea, L. and Castano, J.P. (2006) Cortistatin: not just another somatostatin analog. Nat Clin Pract Endocrinol Metab 2, 356-7.

[24] O'Carroll, A.M. and Krempels, K. (1995) Widespread distribution of somatostatin receptor messenger ribonucleic acids in rat pituitary. Endocrinology 136, 5224-7.

[25] Day, R., Dong, W., Panetta, R., Kraicer, J., Greenwood, M.T. and Patel, Y.C. (1995) Expression of mRNA for somatostatin receptor (sstr) types 2 and 5 in individual rat 
pituitary cells. A double labeling in situ hybridization analysis. Endocrinology 136, 52325.

[26] Mezey, E., Hunyady, B., Mitra, S., Hayes, E., Liu, Q., Schaeffer, J. and Schonbrunn, A. (1998) Cell specific expression of the sst2A and sst5 somatostatin receptors in the rat anterior pituitary. Endocrinology 139, 414-9.

[27] Brown, M.R., Rivier, C. and Vale, W. (1984) Central nervous system regulation of adrenocorticotropin secretion: role of somatostatins. Endocrinology 114, 1546-9.

[28] Kraicer, J., Gajewski, T.C. and Moor, B.C. (1985) Release of pro-opiomelanocortinderived peptides from the pars intermedia and pars distalis of the rat pituitary: effect of corticotrophin-releasing factor and somatostatin. Neuroendocrinology 41, 363-73.

[29] Voight, K.H., Fehm, H.L., Lang, R.E. and Walter, R. (1977) The effect of somatostatin and of prolyl-leucyl-glycinamide (MIF) on ACTH release in dispersed pituitary cells. Life Sci 21, 739-45.

[30] Lamberts, S.W., Zuyderwijk, J., den Holder, F., van Koetsveld, P. and Hofland, L. (1989) Studies on the conditions determining the inhibitory effect of somatostatin on adrenocorticotropin, prolactin and thyrotropin release by cultured rat pituitary cells. Neuroendocrinology 50, 44-50.

[31] Broglio, F., Arvat, E., Benso, A., Gottero, C., Prodam, F., Grottoli, S., Papotti, M., Muccioli, G., van der Lely, A.J., Deghenghi, R. and Ghigo, E. (2002) Endocrine activities of cortistatin-14 and its interaction with GHRH and ghrelin in humans. J Clin Endocrinol Metab 87, 3783-90.

[32] Volpi, R., Chiodera, P., Capretti, L., Caiazza, A., Caffarri, G., Magotti, M.G., Boni, S. and Coiro, V. (1996) Inhibition by somatostatin of the growth hormone, but not corticotropin response to angiotensin II in normal men. Horm Res 45, 269-72. 
[33] Stafford, P.J., Kopelman, P.G., Davidson, K., McLoughlin, L., White, A., Rees, L.H., Besser, G.M., Coy, D.H. and Grossman, A. (1989) The pituitary-adrenal response to CRF-41 is unaltered by intravenous somatostatin in normal subjects. Clin Endocrinol (Oxf) 30, 661-6.

[34] Benso, A., Gottero, C., Prodam, F., Gauna, C., Destefanis, S., Filtri, L., van der Lely, A.J., Deghenghi, R., Ghigo, E. and Broglio, F. (2003) Effects of cortistatin-14 and somatostatin-14 on the endocrine response to hexarelin in humans. J Endocrinol Invest 26, 599-603.

[35] Gottero, C., Prodam, F., Destefanis, S., Benso, A., Gauna, C., Me, E., Filtri, L., Riganti, F., Van Der Lely, A.J., Ghigo, E. and Broglio, F. (2004) Cortistatin-17 and -14 exert the same endocrine activities as somatostatin in humans. Growth Horm IGF Res 14, 382-7.

[36] Luque, R.M., Gahete, M.D., Hochgeschwender, U. and Kineman, R.D. (2006) Evidence that endogenous SST inhibits ACTH and ghrelin expression by independent pathways. Am J Physiol Endocrinol Metab 291, E395-403.

[37] Strowski, M.Z., Kohler, M., Chen, H.Y., Trumbauer, M.E., Li, Z., Szalkowski, D., GopalTruter, S., Fisher, J.K., Schaeffer, J.M., Blake, A.D., Zhang, B.B. and Wilkinson, H.A. (2003) Somatostatin receptor subtype 5 regulates insulin secretion and glucose homeostasis. Mol Endocrinol 17, 93-106.

[38] Iranmanesh, A., Carpenter, P.C., Mielke, K., Bowers, C.Y. and Veldhuis, J.D. (2007) Putative Somatostatin Suppression Potentiates ACTH Secretion Driven by Ghrelin and Human Corticotropin-Releasing Hormone. J Clin Endocrinol Metab.

[39] Silva, A.P., Schoeffter, P., Weckbecker, G., Bruns, C. and Schmid, H.A. (2005)

Regulation of CRH-induced secretion of ACTH and corticosterone by SOM230 in rats. Eur J Endocrinol 153, R7-R10. 
[40] Reubi, J.C., Heitz, P.U. and Landolt, A.M. (1987) Visualization of somatostatin receptors and correlation with immunoreactive growth hormone and prolactin in human pituitary adenomas: evidence for different tumor subclasses. J Clin Endocrinol Metab 65, 65-73.

[41] De Herder, W.W. and Lamberts, S.W. (1999) Octapeptide somatostatin-analogue therapy of Cushing's syndrome. Postgrad Med J 75, 65-6.

[42] Lamberts, S.W., Hofland, L.J., de Herder, W.W., Kwekkeboom, D.J., Reubi, J.C. and Krenning, E.P. (1993) Octreotide and related somatostatin analogs in the diagnosis and treatment of pituitary disease and somatostatin receptor scintigraphy. Front Neuroendocrinol 14, 27-55.

[43] Miller, G.M., Alexander, J.M., Bikkal, H.A., Katznelson, L., Zervas, N.T. and Klibanski, A. (1995) Somatostatin receptor subtype gene expression in pituitary adenomas. J Clin Endocrinol Metab 80, 1386-92.

[44] Panetta, R. and Patel, Y.C. (1995) Expression of mRNA for all five human somatostatin receptors (hSSTR1-5) in pituitary tumors. Life Sci 56, 333-42.

[45] Nielsen, S., Mellemkjaer, S., Rasmussen, L.M., Ledet, T., Olsen, N., Bojsen-Moller, M., Astrup, J., Weeke, J. and Jorgensen, J.O. (2001) Expression of somatostatin receptors on human pituitary adenomas in vivo and ex vivo. J Endocrinol Invest 24, 430-7.

[46] Greenman, Y. and Melmed, S. (1994) Heterogeneous expression of two somatostatin receptor subtypes in pituitary tumors. J Clin Endocrinol Metab 78, 398-403.

[47] Hofland, L.J., van der Hoek, J., Feelders, R., van Aken, M.O., van Koetsveld, P.M., Waaijers, M., Sprij-Mooij, D., Bruns, C., Weckbecker, G., de Herder, W.W., Beckers, A. and Lamberts, S.W. (2005) The multi-ligand somatostatin analogue SOM230 inhibits ACTH secretion by cultured human corticotroph adenomas via somatostatin receptor type 5. Eur J Endocrinol 152, 645-54. 
[48] Batista, D.L., Zhang, X., Gejman, R., Ansell, P.J., Zhou, Y., Johnson, S.A., Swearingen, B., Hedley-Whyte, E.T., Stratakis, C.A. and Klibanski, A. (2006) The effects of SOM230 on cell proliferation and adrenocorticotropin secretion in human corticotroph pituitary adenomas. J Clin Endocrinol Metab 91, 4482-8.

[49] Lamberts, S.W. (1988) The role of somatostatin in the regulation of anterior pituitary hormone secretion and the use of its analogs in the treatment of human pituitary tumors. Endocr Rev 9, 417-36.

[50] Ambrosi, B., Bochicchio, D., Fadin, C., Colombo, P. and Faglia, G. (1990) Failure of somatostatin and octreotide to acutely affect the hypothalamic-pituitary-adrenal function in patients with corticotropin hypersecretion. J Endocrinol Invest 13, 257-61.

[51] Lamberts, S.W., Uitterlinden, P. and Klijn, J.M. (1989) The effect of the long-acting somatostatin analogue SMS 201-995 on ACTH secretion in Nelson's syndrome and Cushing's disease. Acta Endocrinol (Copenh) 120, 760-6.

[52] Fehm, H.L., Voigt, K.H., Lang, R., Beinert, K.E., Raptis, S. and Pfeiffer, E.F. (1976) Somatostatin: a potent inhibitor of ACTH-hypersecretion in adrenal insufficiency. Klin Wochenschr 54, 173-5.

[53] Tyrrell, J.B., Lorenzi, M., Gerich, J.E. and Forsham, P.H. (1975) Inhibition by somatostatin of ACTH secretion in Nelson's syndrome. J Clin Endocrinol Metab 40, $1125-7$.

[54] Stalla, G.K., Brockmeier, S.J., Renner, U., Newton, C., Buchfelder, M., Stalla, J. and Muller, O.A. (1994) Octreotide exerts different effects in vivo and in vitro in Cushing's disease. Eur J Endocrinol 130, 125-31.

[55] van der Hoek, J., Waaijers, M., van Koetsveld, P.M., Sprij-Mooij, D., Feelders, R.A., Schmid, H.A., Schoeffter, P., Hoyer, D., Cervia, D., Taylor, J.E., Culler, M.D., Lamberts, 
S.W. and Hofland, L.J. (2005) Distinct functional properties of native somatostatin receptor subtype 5 compared with subtype 2 in the regulation of ACTH release by corticotroph tumor cells. Am J Physiol Endocrinol Metab 289, E278-87.

[56] Strowski, M.Z., Dashkevicz, M.P., Parmar, R.M., Wilkinson, H., Kohler, M., Schaeffer, J.M. and Blake, A.D. (2002) Somatostatin receptor subtypes 2 and 5 inhibit corticotropinreleasing hormone-stimulated adrenocorticotropin secretion from AtT-20 cells. Neuroendocrinology 75, 339-46.

[57] Cervia, D., Fehlmann, D. and Hoyer, D. (2003) Native somatostatin sst2 and sst5 receptors functionally coupled to $\mathrm{G}(\mathrm{i} / \mathrm{o})$-protein, but not to the serum response element in AtT-20 mouse tumour corticotrophs. Naunyn Schmiedebergs Arch Pharmacol 367, 57887.

[58] Cervia, D., Nunn, C., Fehlmann, D., Langenegger, D., Schuepbach, E. and Hoyer, D. (2003) Pharmacological characterisation of native somatostatin receptors in AtT-20 mouse tumour corticotrophs. Br J Pharmacol 139, 109-21.

[59] Sharif, N., Gendron, L., Wowchuk, J., Sarret, P., Mazella, J., Beaudet, A. and Stroh, T. (2007) Coexpression of somatostatin receptor subtype 5 affects internalization and trafficking of somatostatin receptor subtype 2. Endocrinology 148, 2095-105.

[60] Ben-Shlomo, A., Wawrowsky, K.A., Proekt, I., Wolkenfeld, N.M., Ren, S.G., Taylor, J., Culler, M.D. and Melmed, S. (2005) Somatostatin receptor type 5 modulates somatostatin receptor type 2 regulation of adrenocorticotropin secretion. J Biol Chem 280, 24011-21.

[61] Nolan, L.A., Schmid, H.A. and Levy, A. (2007) Octreotide and the novel multireceptor ligand somatostatin receptor agonist pasireotide (SOM230) block the adrenalectomyinduced increase in mitotic activity in male rat anterior pituitary. Endocrinology 148, 2821-7. 
[62] Arnaldi, G., Polenta, B., Cardinaletti, M. and Boscaro, M. (2005) Potential indications for somatostatin analogs in Cushing's syndrome. J Endocrinol Invest 28, 106-10.

[63] Boscaro, M., Bertherat, J., Ludlam, W., Atkinson, A.B., Petersenn, S., Reincke, M., Snyder, P., Tabarin, A., McBride, K., Findling, J., Gao, B., Freda, P., Frohman, L., Grossman, A., Melmed, S., Biller, B.M. and Glusman, J.E. (2006) The novel multiligand somatostatin analogue pasireotide (SOM230) is a potential medical therapy for patients with Cushing's disease: preliminary results from a phase II clinical study. Abstract OC7.50 12th meeting of the European Neuroendocrine Association.

[64] Pecori Giraldi, F., Andrioli, M., De Marinis, L., Bianchi, A., Giampietro, A., De Martin, M., Sacco, E., Scacchi, M., Pontecorvi, A. and Cavagnini, F. (2007) Significant GH deficiency after long-term cure by surgery in adult patients with Cushing's disease. Eur J Endocrinol 156, 233-9.

[65] Weckbecker, G., Briner, U., Lewis, I. and Bruns, C. (2002) SOM230: a new somatostatin peptidomimetic with potent inhibitory effects on the growth hormone/insulin-like growth factor-I axis in rats, primates, and dogs. Endocrinology 143, 4123-30.

[66] Schonbrunn, A. (1982) Glucocorticoids down-regulate somatostatin receptors on pituitary cells in culture. Endocrinology 110, 1147-54.

[67] Xu, Y., Berelowitz, M. and Bruno, J.F. (1995) Dexamethasone regulates somatostatin receptor subtype messenger ribonucleic acid expression in rat pituitary GH4C1 cells. Endocrinology 136, 5070-5.

[68] Park, S., Kamegai, J. and Kineman, R.D. (2003) Role of glucocorticoids in the regulation of pituitary somatostatin receptor subtype (sst1-sst5) mRNA levels: evidence for direct and somatostatin-mediated effects. Neuroendocrinology 78, 163-75. 
[69] van der Hoek, J., Lamberts, S.W. and Hofland, L. (2007) Preclinical and clinical experiences with the role of somatostatin receptors in the treatment of pituitary adenomas. European Journal of Endocrinology 156, S45-S51. 